\title{
Penerapan tiga terapi fisik modalitas terhadap nilai Ankle Brachial Index (ABI) pada pasien diabetes melitus tipe 2
}

\section{Application of three physical therapy modalities to the value of the Ankel Brachial Index (ABI) in patients with type 2 diabetes mellitus}

\author{
Fischa Awalin 1,*, Ikhsan Ibrahim², Iyar Siswandi ${ }^{3}$ \\ Leni Rosita $^{4}$, Sri Suryati ${ }^{5}$, Yani Sofiani ${ }^{6}$ \\ 1, 2,3,4,5,6 Univeritas Muhammadiyah Jakarta, Jalan K.H. Ahmad Dahlan, Cireundeu, Ciputat Timur., Kota \\ Tangerang Selatan, Banten 15419, Indonesia \\ email: endokrin888@gmail.com* \\ * Corresponding author \\ Tanggal Submit: 30 Desember 2020 Tanggal Penerimaan: 30 Desember 2020
}

\begin{abstract}
Abstrak
Penelitian ini bertujuan untuk melihat intervensi terapi modalitas terhadap nilai ABI pada penderita diabetes mellitus. Desain penelitian adalah quasi experiment prepost test two groups dengan 68 responden. Hasil penelitian menunjukkan ada peningkatan nilai ABI sesudah dilakukan intervensi. Kesimpulan dari penelitian ini adalah terjadi peningkatan nilai ABI pada kelompok setelah dilakukan intervensi. Intervensi terapi fisik modalitas dapat direkomendasikan sebagai terapi alternatif sebagai pencegahan komplikasi penyakit arteri perifer.
\end{abstract}

Kata kunci: ankle brachial index; terapi fisik modalitas; diabetes mellitus tipe II

\begin{abstract}
This study aims to see the modality therapeutic intervention on the ABI value in people with diabetes mellitus. The research design was a quasi experiment pre posttest two groups with 68 respondents. The results showed that there was an increase in the ABI value after intervention. The conclusion is that there is an increase in the ABI value in the group after the intervention. Physical therapy intervention modalities can be recommended as alternative therapies for the prevention of complications of peripheral artery disease
\end{abstract}

Keywords: ankle brachial index; physical therapy modalities; diabetes mellitus type II; 


\section{PENDAHULUAN}

Diabetes mellitus telah menjadi masalah kesehatan masyarakat di seluruh dunia khususnya di negara berkembang, karena tingginya angka komplikasi akibat penyakit tersebut. Diabetes mellitus merupakan penyakit kronis yang memerlukan pengawasan medis, edukasi dan perawatan diri secara berkelanjutan sebagai pencegahan terhadap terjadinya komplikasi (Tanto, 2014).

Internasional Diabetes Federation (IDF) mengungkapkan prevalensi diabetes di dunia pada tahun 2015 sebanyak 415 juta orang, prevalensi ini mengalami peningkatan setiap tahunnya dimana pada tahun 2013 terdapat hanya 382 juta orang. Jumlah pasien diabetes di Asia Tenggara sebanyak 87 juta orang dimana Indonesia menempati urutan ke-7 dunia yaitu sebesar 10 juta orang, Meksiko 11,5 juta orang, Rusia 12,3 juta orang, Amerika serikat 29,3 juta orang, India 69,2 juta orang, dan Cina 109,6 juta orang (IDF, 2015). Berdasarkan data Riset Kesehatan Dasar (Riskesdas, 2018), prevalensi diabetes melitus di Indonesia dari tahun 2013 mengalami peningkatan angka pasien dengan karakteristik usia 15 tahun keatas dan telah didiagnosis oleh dokter dari 1,5\%, menjadi 2,0\% sampai tahun 2018.

Kondisi hiperglikemia yang tidak terkontrol dalam waktu yang cukup lama membuat pasien diabetes mellitus rentan terhadap munculnya berbagai penyakit. Salah satunya adalah penyakit arteri perifer yang sangat erat kaitannya dengan sirkulasi aliran darah, terjadi karena viskositas yang salah satunya disebabkan oleh penumpukan kadar gula darah yang berlebihan sehingga mempengaruhi fungsi platelet darah. Kekentalan darah mengakibatkan aliran darah terganggu sehingga menyebabkan penurunan perfusi aliran darah kebagian ekstremitas bawah untuk membawa nutrisi dan oksigen menuju serabut saraf. Dampak dari tidak adekuatnya aliran darah yang membawa nutrisi yang dibutuhkan oleh tubuh sehingga terjadi penyakit tersebut yang bisa menyebabkan ulkus diabetik dan berakhir dengan amputasi (Black \& Hawks, 2014).

Gangguan sirkulasi perifer tersebut dapat dideteksi dengan melihat nilai Ankle Brachial Index (ABI). ABI merupakan pemeriksaan non infasif pembuluh darah yang berfungsi untuk mendeteksi adanya tanda dan gejala pembuluh darah prefer seperti iskemia (AHA, 2014). Pengukuran ABI dilakukan dengan mengukur rasio dari tekanan sistolik di lengan dan diukur dengan tekanan sistolik di kaki, nilai ABI dihitung dengan membagi antara tekanan sistolik yang berada di lengan dan tekanan sistolik di kaki. Nilai ABI > 1,0 dikatakan baik atau normal dan apabila $<0,91$ dikatakan berisiko terjadi gangguan sirkulasi perifer (Williams \& Wilkins, 2012).

Pencegahan penyakit arteri perifer dapat dilakukan dengan cara memodifikasi gaya hidup serta melakukan perawatan kaki (Iraj et al, 2013). Menurut penelitian yang dilakukan oleh Sihombing, Nursiswati \& Prawesti (2012), menyatakan bahwa perawatan kaki secara teratur dapat mengurangi risiko penyakit kaki diabetik sebesar 50-60\%. Perawatan kaki merupakan pencegahan primer agar tidak terjadi ulkus diabetikum seperti pembersihan kaki memakai kaos kaki yang tepat serta melakukan latihan kaki.

Latihan kaki adalah suatu latihan fisik untuk perawatan kaki yang dapat diberikan kepada pasien Diabetes Melitus untuk mencegah terjadinya komplikasi penyakit arteri perifer dengan tujuan untuk meningkatkan sirkulasi perifer. Adapun jenis latihan kaki seperti kegiatan senam kaki diabetik, yoga, renang, bersepeda, buerger allen exercise dan tiga terapi fisik modalitas. Salah satu latihan kaki yang lebih efektif, mudah dipelajari dan sangat murah serta memiliki risiko yang rendah yaitu tiga terapi fisik modalitas (Nicastri et al, 2013).

Tiga terapi fisik modalitas adalah suatu latihan fisik yang diterapkan dengan menggunakan tiga gerakan ekstemitas bawah pada serangkaian gerak nada yang teratur, terarah, serta terencana yang dilakukan secara sendiri atau berkelompok dengan maksud meningkatkan kemampuan fungsional raga pada pasien diabetes mellitus (Nicastri et al 2013). 
Gerakan pertama terdiri dari pasien duduk dengan mengangkat tangan kedepan lalu berdiri dan berjinjit diakhiri dengan duduk kembali. Gerakan kedua dilakukan dengan melakukan dorsofleksi pada kaki sambil berdiri yang diikuti dengan gerakan plantarfleksi. Gerakan ketiga dilakukan dengan menggerakan kaki dorsofleksi yang diikuti dengan gerakan fleksi plantar pada metatarsus-phalax. Keefektifan kinerja tiga terapi fisik modalitas ditegaskan pada penelitian Nicastri et al (2013) yang menunjukkan hasil bahwa terjadi perbaikan nilai Ankle Brachial Index setelah dilakuan intervensi tersebut yang menunjukkan hasil bahwa terjadi perbaikan nilai Ankle Brachial Index setelah dilakuan intervensi tersebut. Latihan tiga terapi fisik modalitas tersebut dapat dilakukan sebagai salah satu upaya perbaikan nilai Ankle Brachial Index pada pencegahan terjadinya penyakit arteri perifer yang dapat menyebabkan terjadinya ulkus diabetik

\section{METODE PENELITIAN}

Penelitian ini merupakan suatu penelitian dengan pendekatan kuantitatif menggunakan desain quasi eksperiment pre dan post-test two groups. Penelitian ini bertujuan untuk mengetahui efektivitas tiga terapi fisik modalitas terhadap nilai Ankle Brachial Index (ABI). Intervensi pada penelitian ini dilakukan pada dua kelompok. Kelompok intervensi A sebanyak 34 responden diberikan perlakuan tiga terapi fisik modalitas dan pada kelompok B sebanyak 34 responden menjadi kelompok kontrol dan tidak diberikan perlakuan. Populasi dalam penelitian ini adalah semua pasien diabetes mellitus yang berada di wilayah kerja Desa Pao Sulawesi Selatan, Desa Desa Bantulanteh NTB, Desa Karang Ampel Jawa Barat, Desa Poris Tengerang Banten dan Kecamatan Kramat Jati DKI Jakarta. Sampel penelitian adalah pasien diabetes mellitus tipe II yang diambil secara acak.

Penelitian ini dilakukan di desa Pao Sulawesi Selatan, desa Desa Bantulanteh NTB, Desa Karang Ampel Jawa Barat, Desa Poris Tengerang Banten dan Kecamatan Kramatjati DKI Jakarta, sehingga memungkinkan untuk memperoleh sampel sesuai dengan kriteria inklusi. Penelitian ini dilaksanakan dimulai dari persiapan penelitian dan proposal diajukan pada tanggal 01 Januari 2020 dan pengumpulan data dilakukan kurang dari sebulan, yaitu pada tanggal 29 Juni sampai 15 Juli 2020. Dalam penelitian ini proses pengambilan dan pengumpulan data diperoleh dengan kuesioner karateristik dan lembar observasi pengukuran ABI. Alat yang digunakan dalam pengukuran ABI adalah Vaskuler Doppler Ultrasound Probe dan Sphygnomanometer. Variabel bebas dalam penelitian ini adalah tiga terapi fisik modalitas, variable terikat adalah ABI, counfonding (perancu) yang terdiri dari usia, riwayat merokok, riwayat hipertensi dan lama menderita DM serta pekerjaan

Proses pengumpulan data dilakukan selama 17 hari. Sebelum dilakukan intervensi terlebih dahulu dilakukan pengukuran nilai ABI, kemudian diukur kembali pada saat hari ke tiga setelah intervensi, begitu juga dengan kelompok kontrol. Analisa data dilakukan secara univariat, bivariat menggunakan uji-T yang sebelumnya dilakukan uji normalitas dengan uji kolmonogrov-smirnov.

\section{HASIL DAN PEMBAHASAN}

Penerapan tiga latihan fisik modalitas terhadap peningkatan nilai ankle brachial index (ABI) pada pasien diabetes mellitus tipe 2 .

Tabel 1. Distribusi responden berdasarkan usia, riwayat merokok, riwayat hipertensi, dan lama menderita pada pasien diabetes mellitus Juni-Juli $2020(n=68)$

\begin{tabular}{lrrrr}
\hline \multirow{2}{*}{ Variabel } & \multicolumn{2}{c}{ Intervensi } & \multicolumn{2}{c}{ Kontrol } \\
\cline { 2 - 4 } & F & $(\%)$ & F & $(\%)$ \\
\hline
\end{tabular}




\begin{tabular}{lcccc}
\hline Usia & & & & \\
$\leq 44$ & 2 & 5,9 & 1 & 2,9 \\
$45-59$ & 22 & 64,7 & 24 & 70,6 \\
$>60$ & 10 & 29,4 & 9 & 26,5 \\
\hline Riwayat Merokok & & & & \\
Ya & 12 & 35,3 & 12 & 35,3 \\
Tidak & 22 & 64,7 & 22 & 64,7 \\
\hline Riwayat Hipertensi & & & & \\
Ya & 19 & 55,9 & 18 & 52,9 \\
Tidak & 15 & 44,1 & 16 & 47,1 \\
\hline Lama Menderita DM & & & & \\
$\leq 5$ Tahun & 12 & 35,3 & 18 & 52,9 \\
$>5$ Tahun & 22 & 64,7 & 16 & 47,1 \\
\hline Pekerjaan & & & & \\
IRT & 20 & 58,8 & 18 & 52,9 \\
Tani & 7 & 20,6 & 6 & 17,7 \\
Wiraswasta & 4 & 11,8 & 5 & 14,7 \\
Swasta & 3 & 8,8 & 5 & 14,7 \\
\hline
\end{tabular}

Berdasarkan tabel 1 diperoleh data bahwa karakteristik umur pada kedua kelompok intervensi dan kelompok kontrol memiliki variasi yang sama dengan kategori umur terbanyak yaitu 45-59 tahun, adapun dilihat dari karakteristik dengan riwayat merokok kelompok intervensi dan kelompok kontrol memiliki variasi riwayat merokok yang sama. Pada riwayat hipertensi, kelompok intervensi memiliki riwayat hipertensi lebih tinggi dibandingkan dengan kelompok kontrol. Pada riwayat lama menderita diabetes mellitus pada kaelompok intervensi lebih banyak dengan variasi karakteristik $\geq 5$ tahun menderita diabetes mellitus dari pada kelompok kontrol, sedangkan kategori pekerjaan pada kelompok intervensi dan kontrol memiliki riwayat pekerjaan yang sama banyak yaitu sebagai IRT.

Hasil pelaksanaan EBP menunjukkan bahwa karakteristik umur pada kedua kelompok memiliki variasi yang hampir sama, pada kelompok intervensi dan kelompok kotrol berada pada rentang usia 45-49 tahun. Usia sangat erat kaitannya dengan terjadinya kenaikan kadar glukosa darah, sehingga semakin meningkat usia maka prevalensi diabetes dan gangguan toleransi terhadap glukosa semakin tinggi, berdampak pada komplikasi diabetes mellitus termasuk gangguan sirkulasi darah ekterimitas bawah (Black \& Hawks, 2014). Proses menua yang berlangsung setelah usia 30 tahun mengakibatkan perubahan anatomis, fisiologis dan biokimia. Perubahan dimulai dari tingkat sel, berlanjut pada tingkat jaringan dan akhirnya pada tingkat organ yang dapat mempengaruhi fungsi homeostasis. Komponen tubuh yang dapat mengalami perubahan adalah sel beta pankreas yang menghasilkan hormon insulin, selsel jaringan target yang menghasilkan glukosa, sistem saraf, dan hormon lain yang mempengaruhi kadar glukosa (Suiraoka, 2012; Roth et al, 2015).

Berdasarkan hasil penelitian Kurniawaty (2016) bahwa usia $\geq 50$ tahun dapat meningkatkan kejadian diabetes melitus tipe II karena penuaan menyebabkan menurunnya sensitivitas insulin dan menurunnya fungsi untuk metabolisme glukosa. Hal tersebut didukung oleh penelitian Kekenusa (2013) bahwa usia $\geq 45$ tahun memiliki risiko 8 kali lipat terkena diabetes mellitus daripada orang yang berumur $<45$ tahun. Menurut Waspadji (2009), dibandingkan usia yang lebih muda, usia lanjut mengalami peningkatan produksi insulin dari hati (hepatic glucose production), cenderung mengalami retensi insulin, dan gangguan sekresi insulin akibat penuaan dan apoptosis sel beta pankreas. 
Menurut ACCF/AHA (2013), usia tua adalah faktor risiko utama seseorang menderita PAP (sebuah kondisi penyempitan pembuluh darah arteri yang menyebabkan aliran darah menjadi terganggu terutama kearah tungkai bawah). Risiko PAP meningkat seiring dengan bertambahnya usia, dari 3\% pada pasien $<60$ tahun hingga 20\% pada usia $>75$ tahun dan didapati pula pada pasien usia $\leq 50$ tahun, tetapi jumlah kasusnya sangat kecil. Hubungan usia dan PAP mencerminkan lebih panjangnya lama paparan terhadap faktor-faktor aterogenik disertai efek-efek kumulatif penuaan pada pembuluh darah. Proses penuaan secara alami menyebabkan pembuluh darah pada usia tua lebih rentan mengalami aterosklerosis sehingga menyebabkan gangguan pada sirkulasi perifer. Sel-sel radang, sel endotel dan sel otot polos pembuluh darah pada usia tua berbeda dibandingkan sel-sel pada usia muda (Wang et al, 2012). Hal ini didukung oleh penelitian Simatupang (2013) yang menyatakan bahwa orang dengan usia yang lebih tua berisiko 1,881 kali untuk menderita PAP.

Menurut Black \& Hawks (2014), proses penuaan mengakibatkan perubahan pada dinding pembuluh darah sehingga mempengaruhi transportasi oksigen dan nutrisi ke jaringan. Lapisan intima menebal sebagai akibat proliferasi seluler dan fibrosis. Serabut di lapisan media mengalami kalsifikasi, tipis, dan terpotong, serta kolagen yang menumpuk di lapisan intima dan media. Perubahan tersebut menyebabkan kekakuan pembuluh perifer. Hasil analisis seiring bertambahnya usia, khususnya di atas 45 tahun mulai terjadi peningkatan intoleransi glukosa. Proses penuaan mengakibatkan perubahan dinding pembuluh darah sehingga dapat berpengaruh pada nilai Ankle Brachial Index.

Hasil analisis data pada riwayat merokok menunjukkan kelompok intervensi dan kelompok kontrol memiliki jumlah yang sama terhadap variasi riwayat merokok. Riwayat merokok mempunyai pengaruh terhadap penurunan nilai Ankle Brachial Index dan menandakan adanya gangguan vaskularisasi perifer. Kebiasaan merokok pada pasien diabetes mellitus tipe II dapat memperburuk prognosis penyakit. Berbagai racun yang terkandung dalam rokok dapat menyebabkan penurunan sekresi insulin, menghambat pelepasan insulin dan disfungsi sel beta pankreas (Black and Hwaks, 2014).

Beberapa kandungan racun berbahaya dalam rokok adalah nikotin, tar, dan karbon monoksida. Nikotin menyebabkan perangsangan katekolamin (adrenalin) yang bersifat memacu kerja jantung dan tekanan darah yang berakibat timbulnya hipertensi serta penempelan trombosit ke dinding pembuluh darah. Tumpukan ini memicu peradangan sehingga semakin banyak sampah yang menumpuk di dinding pembuluh darah yang berakibat terjadinya penyempitan pembuluh darah (aterosklerosis) (Brunner \& Suddarth, 2013). Aterosklerosis mengakibatkan vaskuler insufisiensi sehingga aliran darah ke dorsalis pedis, popliteal, dan tibialis juga akan menurun dan mempengaruhi nilai ABI sebagai indikator adanya gangguan vaskularisasi perifer (Black \& Hawks, 2014).

Hasil penerapan EBP menunjukkan bahwa pada karakteristik riwayat hipertensi, kelompok intervensi memiliki riwayat hipertensi lebih tinggi dibandingkan dengan kelompok kontrol. Riwayat hipertensi dapat mempengaruhi hasil rata-rata peningkatan nilai Ankle Brachial Index karena riwayat hipertensi mempunyai pengaruh terhadap penurunan nilai Ankle Brachial Index (Black \& Hawks, 2014). Pada pasien diabetes tipe II juga terjadi gangguan aliran darah ke jantung dikarenakan viskositas darah yang menyebabkan beban jantung untuk memompa darah ke seluruh tubuh semakin meningkat dan lama kelamaan dapat terjadi hipertensi. Berdasarkan hasil penelitian Jelantik (2014) terhadap 50 responden pasien diabetes mellitus tipe II didapatkan $88 \%$ responden menderita hipertensi dan $12 \%$ responden tidak menderita hipertensi. Selain itu, hasil penelitian Valliyot (2013) menunjukkan hasil bahwa orang yang memiliki riwayat hipertensi memiliki risiko 5 kali menderita diabetes mellitus tipe II dibandingkan dengan orang yang tidak memiliki riwayat hipertensi. 
Penelitian Thendria et al (2014) menyatakan bahwa hasil prevalensi PAP hipertensi ditemukan sebesar 21\% (IK 95\% 11-31\%). Hal ini didukung oleh penelitian yang dilakukan oleh Simatupang (2013) yang memperlihatkan terdapat 34 orang $(89,5 \%)$ dengan tekanan darah normal memiliki nilai Ankle Brachial Index normal dan hanya terdapat 4 orang $(10,5 \%)$ dengan Ankle Brachial Index tidak normal. Pada pasien dengan hipertensi terdapat 44 orang (71,0\%) dengan Ankle Brachial Index normal dan 18 orang (29,0 \%) dengan Ankle Brachial Index tidak normal.

Hasil penerapan EBP pada lama menderita diabetes melitus menunjukkan bahwa pada karakteristik responden kelompok intervensi dan kelompok kontrol memiliki lama riwayat diabetes mellitus yang sama yaitu $\leq 5$ tahun. Lamanya waktu seseorang mengalami diabetes melitus dapat memperberat risiko komplikasi. Peningkatan kadar gula darah yang lama mengakibatkan rusaknya lumen pembuluh darah. Kerusakan lumen pembuluh darah akan mempengaruhi sirkulasi perifer menjadi terhambat sehingga dapat menurunkan nilai Ankle Brachial Index, dan berakibat pada terjadinya ulkus diabetikum (Black and Hwaks, 2014).

Hasil penerapan EBN pada kategori pekerjaan, didapatkan bahwa hampir setengah dari responden pada kelompok intervensi dan kelompok kontrol adalah ibu rumah tangga. Hasil ini juga menunjukkan bahwa penderita diabetes mellitus lebih tinggi pada orang yang bekerja. Setiap orang yang memiliki jam kerja tinggi dengan jadwal yang tidak teratur menjadi faktor penting dalam pengelolaan diet. Sementara itu, pada penderita diabetes mellitus yang memiliki pendapatan yang rendah lebih tidak patuh dalam mengelola diet dibandingkan dengan orang yang memiliki pendapatan tinggi. Hal ini dikarenakan orang yang mempunyai pendapatan rendah lebih sedikit berpeluang untuk membeli makanan yang sesuai dengan diet diabetes dari pada yang berpendapatan tinggi.

Tabel. 2 Distribusi rata-rata niali Ankle Brachial Index (ABI) pada pasien diabetes melitus sebelum dan sesudah intervensi pada kedua kelompok intervensi Juni-Juli $2020(n=68)$

\begin{tabular}{|c|c|c|c|c|c|c|}
\hline \multirow[b]{2}{*}{ Variabel } & \multicolumn{3}{|c|}{ Intervensi } & \multicolumn{3}{|c|}{ Kontrol } \\
\hline & Mean & $\begin{array}{l}\text { Min- } \\
\text { Maks }\end{array}$ & CI & Mean & Min-Maks & CI \\
\hline Pre & 0,808 & $\begin{array}{c}(0,59- \\
0,90)\end{array}$ & $\begin{array}{c}0,7815- \\
0,8362\end{array}$ & 0,823 & $(0,90-0,90)$ & $\begin{array}{c}0,8053- \\
0,8423\end{array}$ \\
\hline Post & 0,884 & $\begin{array}{c}(0,72- \\
1,20) \\
\end{array}$ & $\begin{array}{c}0,8533- \\
0,9161 \\
\end{array}$ & 0,821 & $(0,30-0,91)$ & $\begin{array}{c}0,7773- \\
0,8656 \\
\end{array}$ \\
\hline
\end{tabular}

Tabel 2 menunjukkan bahwa ada peningkatan nilai Ankle Brachial Index (ABI) setelah dilakukan intervensi pada kelompok intervensi dibandingkan dengan kelompok kontrol.

Tabel. 3 Perubahan nilai Ankle Brachial Index (ABI) pasien diabetes mellitus kelompok intervensi Juni-Juli $2020(\mathrm{n}=68)$

\begin{tabular}{lccc}
\hline \multirow{2}{*}{ Kelompok } & \multicolumn{2}{c}{ Pengukuran Ankle Brachial Index } & \multirow{2}{*}{$\boldsymbol{P}$} \\
\cline { 2 - 3 } & Mean & SD & \\
\hline Pre & 0,808 & 0,078 & \multirow{2}{*}{0,001} \\
\hline Post & 0,884 & 0,090 & \\
\hline
\end{tabular}

Berdasarkan tabel 3 didapatkan bahwa nilai Ankle Brachial Index (ABI) sesudah dilakukan intervensi mengalami peningkatan dari 0,808 menjadi 0,884. Hasil statistik uji-T (Wilcoxon) menunjukkan $p$-value $=0,001(<0,05)$ yang artinya ada pengaruh intervensi 
penerapan tiga terapi fisik modalitas terhadap nilai Ankle Brachial Index pada pasien diabetes mellitus.

Perlakuan tiga terapi fisik modalitas merupakan suatu proses perawatan kaki dengan mengunakan metode exercise untuk memperbaiki sirkulasi darah perifer pada pasien diabetes mellitus. Proses tersebut dengan menggunakan tiga gerakan ekstemitas bawah dengan serangkaian gerak nada yang teratur, terarah, serta terencana yang dilakukan secara sendiri atau berkelompok dengan maksud meningkatkan kemampuan fungsional raga (Mario, 2013).

Dorsofleksi adalah gerakan menggerakkan telapak kaki kearah tubuh pada bagian atas sedangkan plantarfleksi adalah menggerakkan telapak kaki kearah bagian bawah sehingga merangsang endotel pembuluh darah untuk mengeluarkan atau melepaskan Nitrit Oksida. Nitrit Oksida akan menstimulasi soluble guanilate cyclase $(s G C)$ yang menyebabkan peningkatan sintesa siklik GMP dari guanosin triphosphate (GTP). Peningkatan siklik GMP ini akan menyebabkan otot polos pembuluh darah tersebut relaksasi. Pada saat sel otot-otot polos relaksasi maka pembuluh darah akan vasodilatasi sehingga aliran darah ke perifer kaki menjadi lancar (Purnawarman \& Nurkholis, 2014).

Tabel. 4 Perbedaan nilai Ankle Brachial Index (ABI) pasien diabetes mellitus pada kelompok kontrol Juni-Juli $2020(n=68)$

\begin{tabular}{|c|c|c|c|}
\hline \multirow[t]{2}{*}{ Kelompok } & \multicolumn{2}{|c|}{$\begin{array}{l}\text { Pengukuran Ankle Brachial } \\
\text { Index }\end{array}$} & \multirow[t]{2}{*}{$p$} \\
\hline & Mean & SD & \\
\hline Pre & 0,823 & 0,053 & \multirow{2}{*}{0,019} \\
\hline Post & 0,821 & 0,126 & \\
\hline
\end{tabular}

Berdasarkan tabel 4, didapatkan bahwa nilai Ankle Brachial Index (ABI) kelompok kontrol tidak mengalami peningkatan. Hasil uji statistik menunjukkan $p$-value $=0,019$ (> 0,05), dapat disimpulkan bahwa tidak ada pengaruh nilai Ankle Brachial Index pada pasien diabetes mellitus.

Tabel. 5 Hasil seleksi bivariat uji regresi linier variable confounding dan variabel dependen nilai Ankle Brachial Index (ABI) pasien diabetes mellitus Juni-Juli 2020 ( $\mathrm{n}=68)$

\begin{tabular}{lcc}
\hline Variabel & P-value & Keterangan \\
\hline Usia & 0,271 & Bukan Kandidat \\
Riwayat merokok & 0,034 & Kandidat \\
Riwayat hipertensi & 0,307 & Bukan Kandidat \\
Lama DM & 0,008 & Kandidat \\
Pekerjaan & 0,142 & Kandidat \\
\hline
\end{tabular}

Tabel 5 menunjukkan bahwa hasil analisa seleksi bivariat uji regresi linier pada usia $(p$-value $=0,271)$, riwayat merokok $(p$-value $=0,034)$, hipertensi $(p$-value $=0,307)$, lama DM $(p$ value $=0,008)$ dan pekerjaan $(p$-value $=0,142)$.

Tabel. 6 Pemodelan awal seleksi multivariat pengaruh variabel confounding pada nilai Ankle Brachial Index (ABI) pasien diabetes mellitus Juni-Juli 2020 (n=68)

\begin{tabular}{lcccc}
\hline \multicolumn{1}{c}{ Variabel } & B & Coefficients Beta & P-value & Adjusted R Square \\
\hline Riwayat merokok & 0,022 & 0,120 & 0,567 & \\
Lama DM & $-0,008$ & $-0,352$ & 0,075 & 0,154 \\
Pekerjaan & $-0,010$ & $-0,117$ & 0,519 & \\
\hline
\end{tabular}


Hasil analisis pada tabel 6 menunjukkan bahwa variabel yang harus dikeluarkan dari pemodelan adalah variabel yang nilai $\mathrm{p}>0,05$, dapat disimpulkan ketiga variabel tidak berpengaruh terhadap peningkatan nilai ABI. Pada model summary diperoleh nilai adjusted $R$ square sebesar 0,154 yang artinya persamaan diperoleh mampu menjelaskan peningkatan nilai Ankle Brachial Index ABI hanya 15\%.

Hasil penerapan EBN menunjukkan tidak ada pengaruh antara usia terhadap peningkatan nilai Ankle Brachial Index (ABI) pada pasien diabetes mellitus tipe 2 dengan $p$ value $=0,271(<0,25)$. Hasil ini sejalan dengan penelitian Subroto (2016), bahwa penyakit diabetes mellitus tipe 2 biasanya muncul pada orang yang berusia lebih dari 30 tahun. Diabetes mellitus sering muncul pada usia lanjut dan tidak berpengaruh pada nilai ABI.

Hasil analisis menunjukkan bahwa pasien diabetes mellitus berpotensi menderita berbagai komplikasi. Komplikasi kaki adalah komplikasi yang sering terjadi, meliputi gangguan aliran darah kaki yang dapat dideteksi dengan mengukur Ankle Brachial Index (ABI). Apabila nilai ABI 0,41-0,90, artinya iskemia ringan-sedang yang diindikasikan ada risiko tinggi luka di kaki. Apabila nilai $\mathrm{ABI}<0,4$ diindikasikan kaki sudah mengalami kaki nekrotik, gangren, ulkus, borok. Penelitian Isnaini dan Ratnasari (2018) menunjukkan bahwa dilihat dari faktor usia dengan $p$-value $=0,106$, menandakan tidak ada hubungan antara usia responden dengan peningkatan nilai $\mathrm{ABI}$.

Hasil seleksi bivariat uji regresi linier pada variabel riwayat merokok pada pasien diabetes mellitus menunjukkan $p$-value $=0,034(<0,25)$. Riwayat merokok masuk kandidat dalam permodelan multivariat dengan $p$-value $=0,567(>0,05)$ yang artinya tidak ada pengaruh antara riwayat merokok terhadap peningkatan nilai ABI pada pasien diabetes mellitus tipe 2. Hal ini diperkuat dengan nilai adjusted $R$ square $=0,154$, artinya peningkatan nilai Ankle Brachial Index (ABI) hanya 15\%.

Hasil seleksi bivariat uji regresi linier pada variabel riwayat hipertensi pada pasien diabetes mellitus menunjukkan $p$-value $=0,307(<0,25)$. Dapat disimpulkan bahwa tidak ada pengaruh antara riwayat hipertensi terhadap peningkatan nilai Ankle Brachial Index (ABI) pada pasien diabetes mellitus tipe 2 .

Hasil penerapan EBN ini terdapat pengaruh antara lama menderita DM terhadap peningkatan nilai ABI sebesar $15 \%$. Hasil seleksi bivariat uji regresi linear lama menderita DM diperoleh $p$-value $=0,008(<0,25)$, yang artinya lama menderita DM masuk kandidat dalam permodelan multivarit dengan $p$-value $=0,075(>0,05)$. Dapat disimpulkan bahwa tidak ada pengaruh antara lama menderita DM terhadap penningkatan nilai ABI pada pasien diabetes mellitus tipe 2 . Hal ini diperkuat dengan nilai adjusted $R$ square $=0,154$ yang artinya peningkatan nilai ABI hanya $15 \%$.

Penerapan EBN ini menunjukan bahwa terdapat pengaruh yang kurang signifikan, yaitu $15 \%$ dari lama menderita diabetes mellitus dengan nilai ABI. sejalan dengan penelitian Roza (2015) yang menunjukan bahwa terdapat hubungan antara lama menderita diabetes mellitus dengan nilai ankle brachial index akan menyebabkan keadaan hiperglikemia yang lama, sehingga menyebabkan penumpukan glukosa dalam darah. Kadar glukosa dalam darah yang tinggi secara terus menerus dapat merubah dan merusak jaringan pembuluh darah sehingga pembuluh darah kurang elastis dan terjadi aterosklorosis (Price \& Wilson, 2012). Lama menderita diabetes mellitus tipe 2 dapat menyebabkan terjadinya komplikasi, peningkatan kadar glukosa dalam darah berperan dalam proses terjadinya komplikasi makrovaskuler dan sebagai faktor risiko timbulnya komplikasi makrovaskuler (Smeltzer \& Bare, 2010).

Hasil penerapan EBN ini menunjukkan pengaruh pekerjaan terhadap peningkatan nilai ABI sebesar $15 \%$, dengan hasil seleksi bivariat uji regresi linier variabel pekerjaan pada pasien diabetes mellitus dengan $p$-value $=0,142(<0,25)$, yang artinya pekerjaan masuk 
kandidat dalam permodelan multivarit dengan $p$-value $=0,519(>0,05)$. Dapat disimpulkan bahwa tidak ada pengaruh pekerjaan terhadap peningkatan nilai ABI pada pasien diabetes mellitus tipe 2, yang dibuktikan dengan nilai adjusted $R$ square $=0,154$, artinya peningkatan nilai ABI hanya 15\%. Menurut Marthalena (2010) dalam Anani (2012) responden yang berperan sebagai ibu rumah tangga dan bekerja sebagai wiraswasta mempunyai jadwal makan yang kurang teratur setiap hari. Hasil penelitian Anani (2012) menunjukkan hasil bahwa terdapat hubungan antara kebiasaan makan responden dengan kondisi glukosa darah responden sehingga berpengaruh terhadap peningkatan nilai ABI pada penderita diabetes mellitus.

\section{SIMPULAN}

Nilai Ankle Brachial Index (ABI) sebelum dilakukan intervensi pada kelompok intervensi yaitu 0,808 dan pada kelompok kontrol yaitu 0,823. Setelah dilakukan intervensi, nilai Ankle Brachial Index (ABI) pada kelompok intervensi menjadi 0,884 dan pada kelompok kontrol menjadi 0,821 . Ada peningkatan nilai rata-rata ABI setelah dilakukan intervensi pada kelompok kelompok intervensi dibandingkan kelompok kontol. Tidak ada faktor counfonding yang mempengaruhi peningkatan nilai ABI pada pasien diabetes mellitus tipe 2, dapat dilihat pada nilai $R$ square $=0,154$ yang artinya terjadi peningkatan nilai $\mathrm{ABI}$ hanya sebesar $15 \%$.

\section{SARAN}

Bagi institusi pendidikan keperawatan, intervensi terapi modalitas daapt dipertimbangkan sebagai evidence based practice untuk dijadikan materi ajar bagi mahasiswa. Hasil penelitian ini diharapkan dapat dijadikan sumber referensi baru bagi para pendidik dan mahasiswa sehingga dapat menambah wawasan dalam hal intervensi keperawatan mandiri. Bagi peneliti selanjutnya, diharapkan penelitian ini dapat menjadi bahan kajian dan rujukan untuk melakukan penelitian sejenis dengan sampel yang lebih besar dan kriteria inklusi dan eksklusi yang lebih ketat karena penelitian ini bersifat aplikatif sehingga layak untuk dikembangkan pada ilmu keperawatan.

\section{DAFTAR PUSTAKA}

Anani, Sri., Udiyono, Ari., Ginanjar, Praba. (2012). Hubungan antara perilaku pengendalian diabetes dan kadar glukosa darah pasien rawat jalan diabetes melitus (studi kasus di RSUD Arjawinangun Kabupaten Cirebon). Jurnal Kesehatan Masyarakat, 1(2), $466-478$.

American Heart Association. (2014). Retrieved 2015, from American Heart Association:http://www.heart.org/HEARTORG/Conditions/HighBloodPressure/Pr eventionTreatmentofHighBloodPressure/Potassium-and-High-Blood Pressure_UCM_303243_Article.jsp\#.

Black, Joyce M \& Hawks, Jane Hokanson. (2014). Keperawatan medikal bedah edisi 8. Singapore: Elsevier.

Brunner \& Suddarth. (2013). Buku Ajar keperawatan medikal bedah edisi 8 volume 2. Jakarta: EGC.

IDF. (2015). IDF diabetes atlas sixth edition. Diakses pada tanggal 15 Januari 2020 dari https://www.idf.org/sites/default/files/Atlas-poster 2015_EN.pdf.

Iraj, Heydari., Vida, Radi., Sara, Razmjou., Afsaneh, Amiri. (2009). Chronic complications of diabetes mellitus in newly diagnosed patients, International Journal of Diabetes Mellitus, 2, 61-63. 
Isnaini, Nur., Ratnasari. (2018). Faktor risiko mempengaruhi kejadian Diabetes mellitus tipe dua. Jurnal Kebidanan dan Keperawatan Aisyiyah, 14(1), 59-68.

Jelantik. (2014). Hubungan faktor resiko umur, jenis kelamin, kegemukan, dan hipertensi dengan kejadian DM tipe 2 di wilayah kerja Puskesmas Mataram. Jurnal Media Bina Ilmiah, 8(1).

Kekenusa, John S. (2013). Analisis hubungan antara umur dan riwayat keluarga menderita DM dengan kejadian penyakit DM tipe 2 pada pasien rawat jalan di Poliklinik Penyakit Dalam BLU RSUP Prof. Dr. R. D. Kandou Manado. Jurnal Kesehatan Masyarakat Unsrat, 2(1), 1-6.

Kemenkes RI. (2018). Riset Kesehatan Dasar (RISKESDAS). Jakarta: Balitbang Kemenkes RI.

Kemenkes RI. (2015). Profil Kesehatan Indonesia tahun 2014. Jakarta: Kemenkes RI.

Mario, Adelaida et al. (2013). A program of 3 physical therapy modalities improves peripheral arterial disease in diabetes type 2 patients a randomized controlled trial. Journal of Cardiovascular Nursing, 28(1), pp: 74Y82.

Nicastri, Maria et al. (2013). Efficacy of early physical therapy in severe bell's palsy: a randomized controlled trial. Neurorehabilitation and Neural Repair, 27(6), 542-551.

Price, Sylvia A., Wilson, Lorraine M. (2012). Patofisiologi: konsep klinis proses-proses penyakit. Jakarta: EGC.

Purnawarman, A., \& Nurkhalis. (2014). Pengaruh latihan fisik terhadap fungsi endotel. Jurnal Kedokteran Universitas Syiah Kuala, 14 (2), 109-118.

Roth et al. (2015). Mortality from cardiovascular diseases in sub-Saharan Africa, 1990-2013: a systematic analysis of data from the Global Burden of Disease Study 2013. Cardiovascular Journal of Africa, 26(2 H3Africa Suppl), S6-S10.

Roza, R. L., Afriant, R. (2015). Faktor risiko terjadinya ulkus diabetikum pada pasien diabetes mellitus yang di rawat jalan dan inap RSUP Dr. M. Djamil dan RSI Ibnu Sina Padang. Jurnal Kesehatan Andalas, 4(1).

Sihombing, D., Nursiswati \& Prawesti, A. (2012). Gambaran perawatan kaki dan sensasi sensorik kaki pada pasien diabetes melitus tipe 2 di Poliklinik DM RSUD. Diakses $\begin{array}{lllll}\text { pada } & \text { tanggal } & 11 & \text { Januari } & 2020\end{array}$ http://journals.unpad.ac.id/ejournal/article/view/677.

Bare BG., Smeltzer SC. (2010). Buku ajar keperawatan medikal bedah. Jakarta : EGC.

Suiraoka, IP. (2012). Penyakit Degeneratif; Mengenal, mencegah dan mengurangi faktor resiko 9 penyakit degeneratif. Yogyakarta: Nuha Medika.

Tanto, C. (2014). Kapita selekta kedokteran edisi 4 Jilid 1. Jakarta: Media Aesculapiu.

Thendria, Tessa., Toruan, Ivan Lumban., Natalia, Diana. (2014). Hubungan hipertensi dan penyakit arteri perifer berdasarkan nilai Ankle-Brachial Index. eJournal Kedokteran Indonesia, 2(1).

Valliyot, B Sreedharan., J Muttappallymyali. (2013). Risk factors of type 2 diabetes mellitus in the rural population of North Kerala, India: A case control study. Diabetologi Croatica, 42(1), 33-40.

Wang Y, et al. (2012). Coiled-coil networking shapes cell molecular machinery. Mol Biol Cell, 23(19), 3911-22.

Waspadji S. (2009). Buku ajar penyakit dalam: kaki diabetes, jilid III, edisi 4. Jakarta: FK UI.

Williams \& Wilkins. (2012). Kapita selekta penyakit. Jakarta: EGC.

World Health Organization (WHO). (2012). Metabolik endokrin. http://www.who.int/mediacentre/factsheets/fs317/en/, diakses pada tanggal 9 Januari 2020. 